\title{
Review
}

\section{Dementia and COVID-19, a Bidirectional Liaison: Risk Factors, Biomarkers, and Optimal Health Care}

\author{
Sofia Toniolo ${ }^{\mathrm{a}, *}$, Marta Scarioni ${ }^{\mathrm{b}, \mathrm{c}}$, Francesco Di Lorenzo ${ }^{\mathrm{d}, \mathrm{e}}$, Jakub Hort $^{\mathrm{f}, \mathrm{g}}$, Jean Georges ${ }^{\mathrm{h}}$, \\ Svetlana Tomic $^{\mathrm{i}, \mathrm{j}}$, Flavio Nobili ${ }^{\mathrm{k}, 1}$ and Kristian Steen Frederiksen ${ }^{\mathrm{m}}$, the Management Group of the \\ EAN Dementia and Cognitive Disorders Scientific Panel \\ ${ }^{a}$ Cognitive Neurology Group, Nuffield Department of Clinical Neurosciences, University of Oxford, Oxford, UK \\ ${ }^{\mathrm{b}}$ Department of Neurology, Amsterdam University Medical Centers, Location VUmc, Alzheimer Center, \\ Amsterdam, The Netherlands \\ ${ }^{\mathrm{c}}$ Department of Pathology, Amsterdam University Medical Centers, Location VUmc, Amsterdam Neuroscience, \\ Amsterdam, The Netherlands \\ ${ }^{\mathrm{d}}$ Clinical Imaging Sciences Centre, Brighton and Sussex Medical School, Brighton, UK \\ ${ }^{\mathrm{e}}$ Non-invasive Brain Stimulation Unit, IRCCS Fondazione Santa Lucia, Rome, Italy \\ ${ }^{\mathrm{f}}$ Memory Clinic, Department of Neurology, Charles University, 2nd Faculty of Medicine and Motol University \\ Hospital, Czech Republic

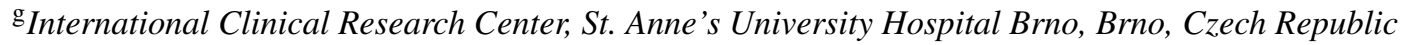 \\ ${ }^{\mathrm{h}}$ Alzheimer Europe, Luxembourg \\ ${ }^{\mathrm{i}}$ Department of Neurology, Osijek University Hospital Center, Osijek, Croatia \\ ${ }^{\mathrm{j}}$ Faculty of Medicine, University Josip Juraj Strossmayer of Osijek, Osijek, Croatia \\ ${ }^{\mathrm{k}}$ Neurology Clinic, IRCCS Ospedale Policlinico San Martino, Genoa, Italy \\ ${ }^{1}$ Department of Neuroscience (DINOGMI), University of Genoa, Genoa, Italy \\ ${ }^{\mathrm{m}}$ Danish Dementia Research Centre, Rigshospitalet, University of Copenhagen, Copenhagen, Denmark
}

Handling Associate Editor: Laura Bonanni

Accepted 14 May 2021

Pre-press 29 May 2021

\begin{abstract}
Cognitive impairment following SARS-CoV-2 infection is being increasingly recognized as an acute and possibly also long-term sequela of the disease. Direct viral entry as well as systemic mechanisms such as cytokine storm are thought to contribute to neuroinflammation in these patients. Biomarkers of COVID-19-induced cognitive impairment are currently lacking, but there is some limited evidence that SARS-CoV-2 could preferentially target the frontal lobes, as suggested by behavioral and dysexecutive symptoms, fronto-temporal hypoperfusion on MRI, EEG slowing in frontal regions, and frontal hypometabolism on ${ }^{18}$ F-FDG-PET. Possible confounders include cognitive impairment due to hypoxia and mechanical ventilation and post-traumatic stress disorder. Conversely, patients already suffering from dementia, as well as their caregivers, have been greatly impacted by the disruption of their care caused by COVID-19. Patients with dementia have experienced worsening of cognitive, behavioral, and psychological symptoms, and the rate of COVID-19-related deaths is
\end{abstract}

*Correspondence to: Dr. Sofia Toniolo, Nuffield Department of Clinical Neurosciences, University of Oxford, New Radcliffe
House, 1st Floor, OX2 6DG, Oxford, United Kingdom. Tel.: +44 01865271310; E-mail: sofia.toniolo@ndcn.ox.ac.uk. 
disproportionately high among cognitively impaired people. Multiple factors, such as difficulties in remembering and executing safeguarding procedures, age, comorbidities, residing in care homes, and poorer access to hospital standard of care play a role in the increased morbidity and mortality. Non-pharmacological interventions and new technologies have shown a potential for the management of patients with dementia, and for the support of their caregivers.

Keywords: Alzheimer's disease, cognition, COVID-19, dementia, SARS-CoV-2

\section{INTRODUCTION}

Cognitive impairment in severe acute respiratory syndrome coronavirus 2 (SARS-CoV-2) infection has frequently been reported, in patients with meningitis, encephalitis, encephalopathy, and acute cerebrovascular disease, but also when no identifiable structural cause can be found [1,2]. Rates of cognitive impairment in COVID-19 patients range widely across studies [2-4], due to different neurological conditions causing cognitive impairment and different evaluation timings and settings [2-4]. Although several pathways have been implicated in viral entry in the central nervous systems (CNS), the presence of the virus is not necessary to elicit neuronal damage, as other detrimental mechanisms such as cytokine storm could play a crucial role in COVID-19 neuroinflammation [5, 6]. Most studies comprehensibly focus on acute cognitive syndromes such as delirium, while longitudinal data on cognition are scarce. The distinction between acute and permanent cognitive decline in the context of COVID-19, though too early to ascertain, is an essential one. Other coronaviruses, such as severe acute respiratory syndrome coronavirus 1 (SARS-CoV-1) and middle east respiratory syndrome (MERS), mostly caused acute confusion, mania and psychosis, and even if residual depression, anxiety, insomnia, memory impairment, post-traumatic stress disorder (PTSD) and fatigue have been described, most patients showed a progressive return to their baseline function [7]. In patients with an established diagnosis of dementia, the available studies point to an increased susceptibility of Alzheimer's disease (AD) patients to COVID-19 infection, and to higher rates of COVID19 deaths [8-11]. Multiple factors, such as difficulties in remembering safeguarding procedures (e.g., wearing masks or adhering to social distance), but also age, genotype, comorbidities, and residing in care homes, have been shown to play a role $[10,12$, 13]. In this review, focusing on the reciprocal link between COVID-19 and dementia, we will examine the possible pathogenic role of COVID-19 in causing cognitive impairment and available biomarkers, and describe the challenges that COVID-19 poses to patients with dementia and their caregivers, as well as possible interventions.

\section{INTERPLAY BETWEEN SARS-COV-2 AND DEMENTIA}

\section{Pathophysiology}

Neuro-invasion by SARS-CoV-2 is thought to be achieved through different mechanisms. One possible way is the hematogenous spread from infected leukocytes, similarly to HIV's Trojan horse, crossing the blood-brain barrier (BBB) [14]. Direct viral invasion through infected vascular endothelial cells directly to glial cells has also been described, as well as penetrance from the olfactory epithelium to the olfactory bulb through retrograde axonal transport along the olfactory nerve [15]. Vagal and glossopharyngeal nerves might also play a role in neuro-invasion and multiorgan dissemination of SARS-CoV-2 [16]. Moreover, angiotensin-converting enzyme 2 (ACE2) receptors control SARS-CoV-2 entry into cells, and their expression in endothelial cells mediates viral invasion across the BBB [15]. Neuropathological and transcriptome-based studies in humans found high ACE-2 expression throughout the brain, especially in the pons, medulla oblongata, substantia nigra, caudate nucleus, spinal cord, hypothalamus, hippocampus, middle temporal gyrus, amygdala, cingulate cortex, frontal cortex, and olfactory bulb [17, 18]. Given that the medulla oblongata contains the respiratory centres of the brain, its involvement might partially explain the susceptibility of many COVID-19 patients to severe respiratory distress [17]. Preclinical evidence on other coronaviruses indicate their greater affinity to CA1 and CA3 hippocampal regions [19]. This does not seem to apply 


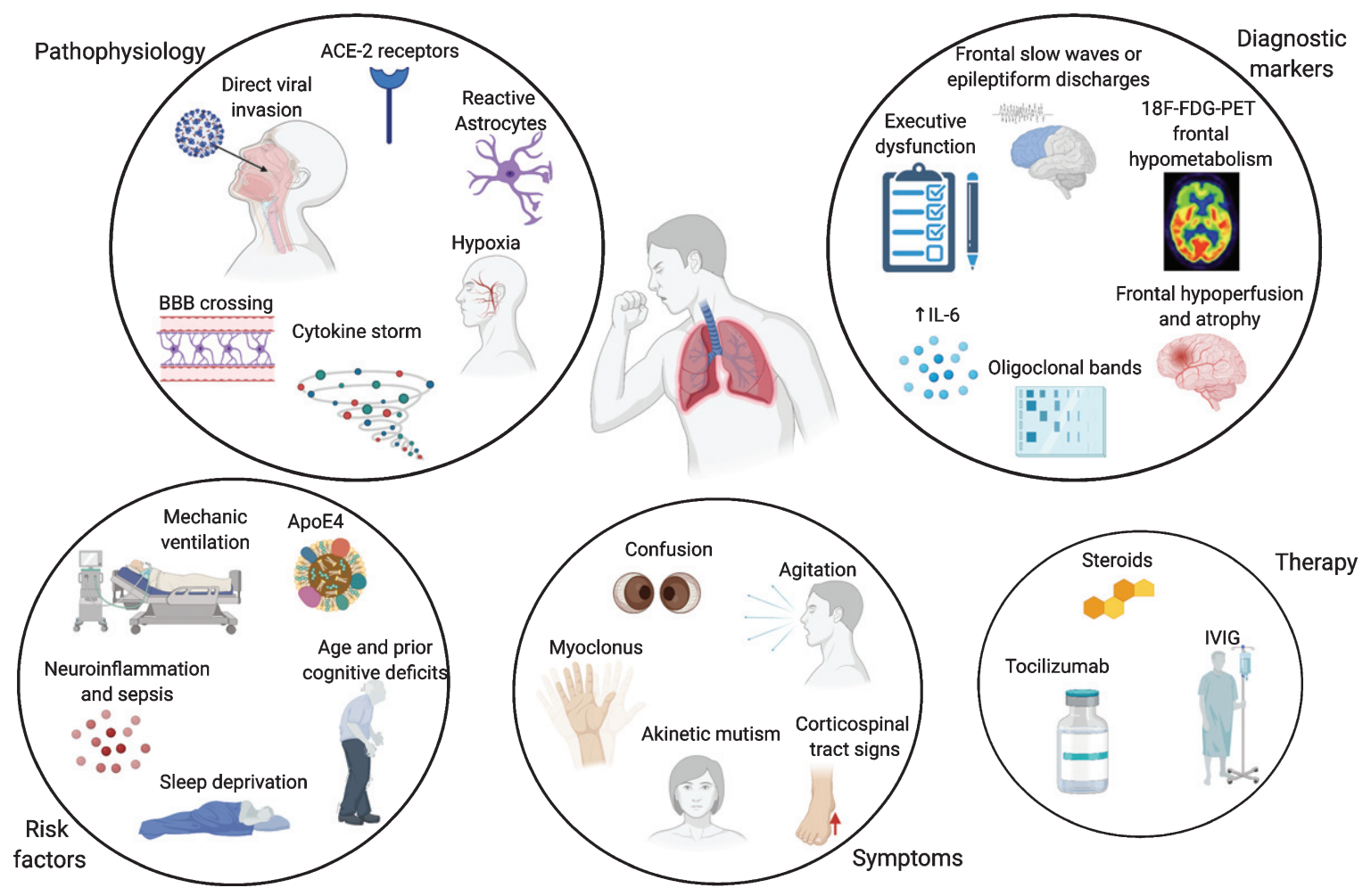

Fig. 1. Overview of the pathophysiological mechanisms, risk factors, symptoms, and biomarkers of cognitive impairment and therapy in COVID-19 patients. Made in @BioRender - biorender.com.

to SARS-CoV-2, as the relatively limited neuropathological data available show a primary involvement of medulla oblongata, basal ganglia, cerebellum, frontal lobes and olfactory bulbs $[6,20]$. No proven cases of AD or frontotemporal dementia (FTD) have been associated to SARS and MERS coronaviruses, but this evidence is limited by small numbers. Despite the growing amount of literature, clinical evidence for viral presence of SARS-CoV-2 in the cerebrospinal fluid (CSF) is still limited, even if viral particles can be found in the brain [20-22]. COVID-19 is often associated with a cytokine storm, with increased release of interleukin 6 (IL-6), tumor necrosis factor alpha (TNF-alpha), interleukin 1 beta (IL-1 $\beta$ ), and interleukin 8 (IL-8), which strongly resembles an immune effector cell-associated neuro-toxicity syndrome (ICANS) [23]. Increased cytokine levels, especially IL-6, have been shown to be positively correlated with COVID-19 severity and mortality, leading to multiorgan failure [24, 25]. This cytokine storm induces a massive activation of macrophages and monocytes and compromises the integrity of the BBB, which in turn, can induce astrocyte and glial cells to produce reactive oxygen species, which would ultimately lead to CNS damage [26]. As a result, markers of BBB disruption, such as serum S100B, and glial activation, as glial fibrillary acidic protein (GFAP), are increased in patients with COVID-19-related encephalopathy [27-29]. Moreover, this cytokine storm is also associated with increased levels of ferritin, lactate dehydrogenase (LDH) and D-dimer, which in turn can lead to an hypercoagulable state and increased cerebrovascular events [30]. Lastly, hypoxia secondary to respiratory insufficiency needs to be considered among the major causative mechanisms leading to transient and possibly permanent cognitive impairment [31] (Fig. 1).

\section{Dementia as a risk factor for COVID-19}

Dementia, and particularly AD, is associated with higher rates of infection and hospitalization due to COVID-19 [9, 32]. A large UK biobank study showed that $\mathrm{AD}$ was the major risk factor for hospital admission for COVID-19 (OR = 2.29) [9]. According to an American study, dementia was associated with an OR of 5.2 and $\mathrm{AD}$ of 7.7 of COVID-19 infection [32]. 


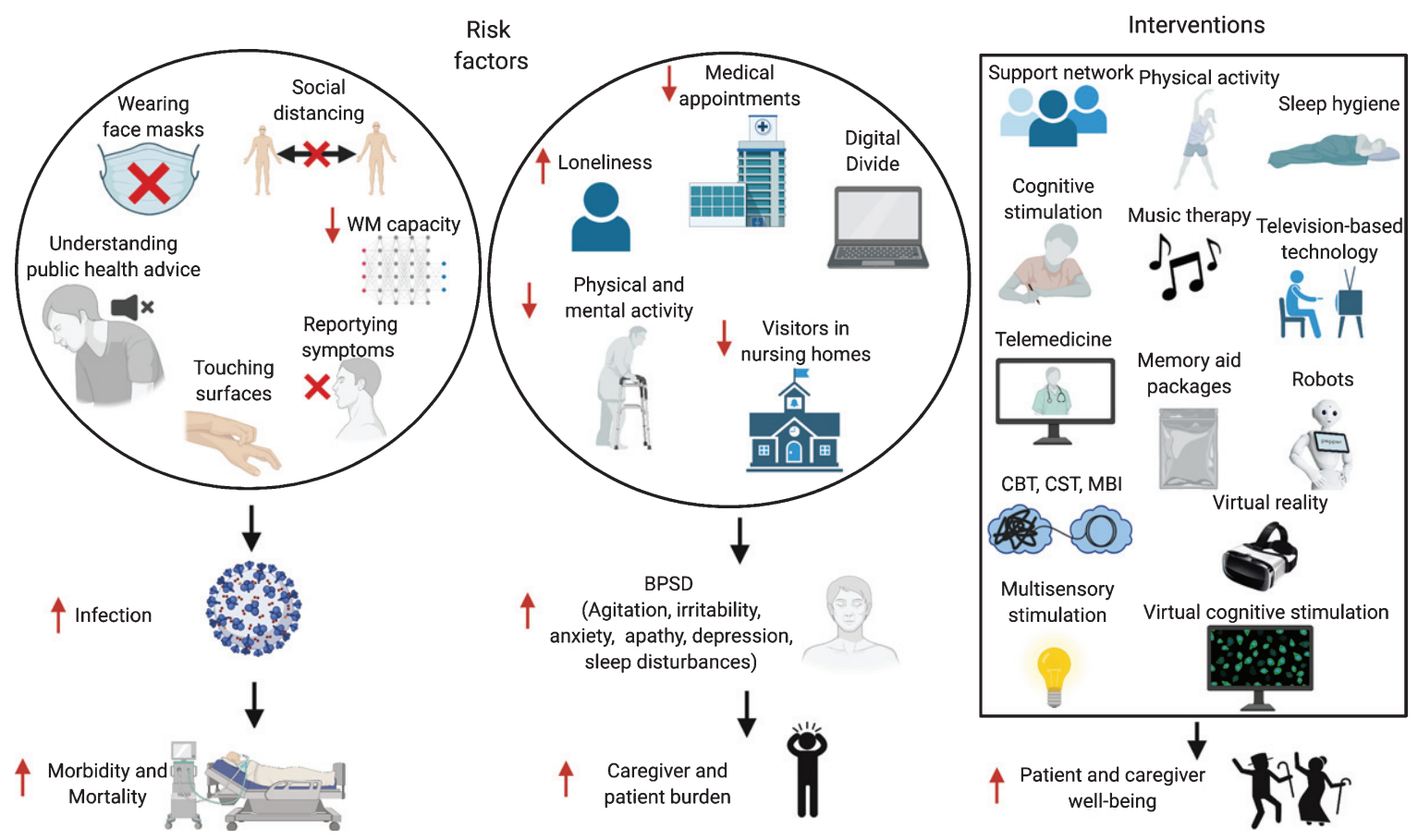

Fig. 2. Risk factors for increased infection rates and BPSD in patients with dementia, and possible interventions. WM, working memory; BPSD, behavioral and psychological symptoms of dementia; CBT, Cognitive Behavioral Therapy; CST, Cognitive Stimulation Therapy; MBI, Mindfulness-Based Intervention. Made in @BioRender - biorender.com.

Multiple factors could contribute to these increased rates of infection. Patients with dementia might have difficulties in remembering safeguarding procedures, such as wearing masks, or understanding the public health information issued [33] (Fig. 2). A Japanese study on AD and FTD patients showed that both patient groups had troubles understanding the meaning of the requests, and $\mathrm{AD}$ patients often forgot the instructions [33], while FTD patients struggled more to follow safeguarding procedures, especially washing hands, social distancing, and staying at home, because of their socially inappropriate and stereotyped behaviors. In care homes, increased intrusiveness and wandering undermine efforts to maintain isolation, thus increasing the risk of contagion $[34,35]$. Even in healthy people, a UK Biobank study showed that over 431,051 healthy subjects an elevated risk of COVID-19 incidence was related to performance on two tests of cognitive function, i.e., verbal and numerical reasoning and reaction speed on a 'Go/No-go task' [36]. Similarly, an American study on 850 healthy subjects found that participants' social-distancing compliance could be predicted by individual differences in working memory (WM) capacity [37], with high WM capacity individuals understanding better the true merits of social distancing. Therefore, it is not surprising that $\mathrm{AD}$ patients, who have lower WM capacity and have poorer response inhibition, could have higher rates of infection.

However, not only is the incidence of COVID-19 higher in patients with dementia, but these patients are also more likely to have more severe presentations, and higher mortality rates due to COVID-19 infection $[10,38]$. An epidemiological study among 185 countries found a significant correlation between burden of dementia and life expectancy, and COVID-19 related deaths [39]. The highest numbers of confirmed cases and deaths were reported in high-income countries, where also the prevalence of dementia is higher, and more patients live in long-term care facilities, where COVID-19 had a higher toll [39]. A cross-country study involving UK, Spain, Ireland, Italy, Australia, US, India, Kenya, and Brazil found that $29 \%-75 \%$ of the deaths in patients with dementia in care homes were linked to COVID-19 [40]. In a UK Biobank study, pre-existing dementia was the most important factor associated with COVID-19 severity $(\mathrm{OR}=3.07)$ [10]. An Italian observational study showed that severe dementia was an independent risk factor for death [38]. In a Korean study, age, chronic lung disease, and $\mathrm{AD}$ were the only 
significant parameters for predicting COVID-19 nonsurvival [41]. A Spanish study in 204 patients with $\mathrm{AD}$ and FTD showed that AD patients had higher mortality rates compared to patients with FTD, even though the $\mathrm{AD}$ ones were older in this study, and that risk of death was much more common in patients living in care homes (72.0\%) compared to homedwelling patients $(7.3 \%)$, regardless of the etiology [13].

Several explanations might account for the higher rate of COVID-19 mortality in patients with dementia. This has often been attributed exclusively to age, but comorbid diseases such as AD may be more influential than aging [42, 43], and age and dementia are independently associated with a higher mortality [44]. Moreover, there might be local hospital guidelines and ethical reasons accounting for higher mortality in patients with dementia. In case of shortage of ventilators, rationing of health care may be required, which could result in elderly patients with dementia being denied intensive care or ventilatory support, resulting in higher mortality [45, 46]. Reports of 'ageism', i.e., discrimination against elderly people, and especially patients with dementia, have been frequently described during the COVID-19 pandemic [40]. As an example, in the UK, people living with dementia often reported being denied access to hospital or being told that they had to sign "do not attempt resuscitation (DNAR)" arrangements [40]. Alzheimer Europe has made a public statement that a diagnosis of dementia should never be a reason to refuse people access to treatment, care and support, as would violate basic human rights [47]. Ethical considerations arise also when artificial intelligence is proposed to optimize triage [48].

\section{Shared biological links between dementia and COVID-19 infection}

Several shared neurobiological substrates have been suggested to mediate the pathological synergy between AD and COVID-19 infection [49]. While ACE-2 receptors overexpression could facilitate viral access into the CNS, their role in neurodegenerative diseases is still debated, with some evidence claiming that the physiological decline in ACE-2 expression could explain the increased severity of cognitive symptoms in elderly patients [50], while other advocate a neuroprotective effect $[51,52]$. PreCOVID-19 data showed reduced ACE-2 levels in AD, which inversely correlated with $A \beta$ and tau burden [51-53]. On the other hand, preliminary preprint data from COVID-19 patients with AD show that ACE-2 levels are actually upregulated in AD brains [54], and increased ACE-2 levels could therefore constitute an intrinsic vulnus and an additional risk factor for viral entry.

APOE4 genotype, a known risk factor for lateonset sporadic $\mathrm{AD}$, has been acknowledged as a possible additional predisposing factor for COVID19 infection and severity [55] (Fig. 1). A UK-Biobank study showed that, after adjusting for pre-existing dementia, hypertension, coronary artery disease, and Type-2 diabetes, APOE4 homozygotes have a 2.2fold increased risk for COVID-19 infection, and more severe outcomes, specifically a 4.3-fold case-fatality rate, compared to $A P O E 3$ homozygotes $[10,12,56]$. This finding has been questioned with respect to the adjustment of $p$-value in genome-wide association studies (GWAS) and possible selection bias [57, 58]. Its replication could help to unravel a possible detrimental effect of ApoE4 in inducing neuroinflammatory microglia response, as in $\mathrm{AD}$ [59], and further neurodegeneration in COVID-19 patients [51].

Another possible biological link between COVID19 and AD is represented by a pro-inflammatory cytokine profile. IL- 6 and IL- $1 \beta$ have been frequently associated with increased mortality in COVID-19 patients [2], and currently IL-6 and IL- $1 \beta$ inhibitors, such as tocilizumab and anakinra, are among the most used treatment options for COVID-19 [60, 61] (Fig. 1). Neuroinflammation has received much attention in recent years as a driver of cognitive impairment in AD [62]. Pre-COVID-19 data indicate that inflammatory markers in $\mathrm{AD}$ show different patterns across disease progression, with some cytokines peaking in the prodromal phase and then declining, while others, including IL-1 $\beta$ and IL-6, increasing alongside disease progression [63-65]. Preclinical data in animal models of $\mathrm{AD}$ show that counteracting inflammation leads to better cognitive performances [66-68], while evidence on the use of anti-inflammatory drugs in $\mathrm{AD}$ has been inconclusive, given their poor BBB permeability [69]. SARS-CoV-2 open reading frame $3 \mathrm{a}$ (ORF3a) protein stimulates NLRP3 inflammasome, which has also been found to cause pathological accumulation of $A \beta[70,71]$. Galectin-3, a key element in COVID-19 inflammation [72], is involved in $A \beta$ oligomerization and toxicity, and has been proposed as shared anti-inflammatory target [73]. Nevertheless, these potential mechanisms remain speculative at the moment, given the absence of reliable postmortem data on $A \beta$ and neurofibrillary tangles in COVID-19 patients. 
Delirium as a clinical presentation of COVID-19 patients with dementia: Cognitive features and biomarkers

Among patients diagnosed with dementia, one of the most frequent symptoms of COVID-19 at onset is delirium, especially in the hypoactive form [74, 44]. By contrast, fever, cough, and dyspnea are less common $[38,75,76]$. A French study in 353 elderly showed that patients with dementia compared to those without, more often exhibited hypoactive (27.6\% versus $11.4 \%)$ and hyperactive delirium (14.9\% versus $5.5 \%$ ), altered consciousness (17.2\% versus $6.4 \%)$, and lymphopenia $(79.3 \%$ versus $66.7 \%$ ), and less often hyperthermia ( $47.0 \%$ versus $61.6 \%$ ), cough (46.3\% versus $66.7 \%)$ and loss of taste $(2.3 \%$ versus $10.1 \%$ ) [77]. Prevalence of delirium increases with age and with more severe cognitive impairment, and can be associated with as high as 17 times greater mortality rates [74].

Pharmacological management has also been implicated in induction or exacerbation of delirium in COVID-19 patients [110, 111]. Benzodiazepines (BDZ) $(\mathrm{OR}=1.59)$, opioids ( $\mathrm{OR}=1.39)$, antipsychotics $(\mathrm{OR}=1.59)$ and vasopressor infusions $(\mathrm{OR}=1.25)$ have been found to be associated with a higher risk of delirium in these patients [110]. Pharmacodynamic interactions with drug-induced effects on increased QTc prolongation. coagulation abnormalities, and immunosuppression also need to be considered in COVID-19 patients [112]. Haloperidol has shown a favorable profile in terms of morbidity and mortality, while BDZ and anticholinergic drugs should be avoided for the high risk of respiratory depression and confusion $[110,112]$. Whenever possible, non-pharmacological management of agitation should be preferred, in order to avoid acute delirium and a post-intensive care syndrome (PICS) [110].

Given the high frequency of delirium in patients with COVID-19 infection, it is crucial to understand whether there are any specific cognitive, imaging, electrophysiological, or laboratory predictors (biomarkers) of CNS involvement. Moreover, it is important to ascertain whether these elderly COVID19 patients with delirium are more likely to develop a neurodegenerative disorder in the future or are already affected by preclinical disease. There is some limited evidence that SARS-CoV-2 could preferentially target the frontal lobes [78-82] (Fig. 1). A clinical phenotype characterized by acute frontal type behavior such as attention deficits, abulia, alogia, absence of goal directed behavior, frontal release signs and myoclonus, has been frequently described in hospitalized COVID-19 patients, whether in intensive care unit (ICU) on non-ICU wards [83-85]. At neuropsychological testing, deficits in frontal lobe functions have been reported, even in young COVID19 patients, and seem to be correlated with the severity of respiratory symptoms and mechanical ventilation, but not with gender, length of ICU stay or duration of mechanical ventilation [86-88]. In these cases, magnetic resonance imaging (MRI) findings can be either unremarkable, or show fronto-temporal hypoperfusion at arterial spin labeling, or even atrophy in multiple regions, including the frontal grey matter $[78,83,88]$. Electroencephalogram (EEG) frequently shows frontal abnormalities, including slow waves or epileptiform discharges, in up to $1 / 3$ of the cases, and has recently been proposed as a biomarker for COVID-19 encephalopathy [89]. An inflammatory profile in the CSF, such as increased IL-6 or oligoclonal bands has also been described [78, 83, $79,80,90]$. Frontal hypometabolism on positron emission tomography with F-18 fluorodeoxyglucose (FDG-PET) imaging has been reported in these patients with acute frontal type behavioral changes $[79,80]$. Moreover, frontal hypometabolism is found in COVID-19 patients without evidence of acute delirium or frontal signs, but with anosmia and ageusia, and in old as well as young patients [90]. PreCOVID-19 literature on 18F-FDG-PET in patients with delirium is not vast, but the few available studies show a more diffuse pattern of hypometabolism [91, 92]. There are no pre-delirium scans in most COVID19 studies, so these changes might also reflect in some studies premorbid patterns of cognitive impairment as in AD or FTD, delirium potentially being only an epiphenomenon [93]. Nevertheless, even in patients with no previous history of cognitive impairment, there are reports of a fronto-parietal 18F-FDG-PET hypometabolism coupled with relative striatal and cerebellar hypermetabolism in the acute stage of COVID-19, which correlates with the degree of cognitive impairment at testing $[94,95]$. After 6 months, one study showed a significant reduction of an initial frontoparietal hypometabolism, accompanied by a significant improvement in cognition, even if there were still residual mild deficits at neuropsychological testing and their 18F-FDG-PET did not completely revert back to normal [94].

What is the underlying cause of this frontal lobe dysfunction? The role of direct viral damage is at the moment limited, and even if viral particles can be found in the brain, the few neuropathological 
data available argue in favor of an inflammatory process rather than direct damage by SARS-CoV-2, involving primarily the brainstem, cerebellum, and olfactory bulbs, and to a lesser extent, the basal ganglia and frontal lobes $[6,20]$. Notably, in some of these cases, there is evidence that counteracting neuroinflammation could have a positive impact on the patients' outcomes, either through steroids administration, intravenous immunoglobulin (IVIG), or tocilizumab [24, 79, 80, 84, 85] (Fig. 1). The frontal lobes are particularly vulnerable to hypoxic damage, but given the response to immunosuppression, it is unlikely that this is the sole source of the cognitive impairment [96] (Fig. 1). Lack of standardized diagnostic protocols, as well as polymorphic nomenclatures such as COVID-19 related delirium [78], encephalopathy [79], encephalitis [97], akinetic mutism [85], and frontal lobe dysfunction [80], hamper comparability across studies [98]. It is not known whether these patients are more likely to develop FTD or $\mathrm{AD}$ at the present time, and large-scale data on blood and CSF biomarkers of neurodegeneration is lacking, with reports of increased neurofilament light chain and total tau in severe COVID-19 cases [29].

Moreover, COVID-19 is related to increased risk of vascular changes and stroke [99], which can also impact cognition acutely, and are important comorbidities in subjects with cognitive impairment.

\section{Long-term effects on cognition and cognitive profile}

Only future longitudinal data will be able to assess the long-term impact of COVID-19 on cognition. Currently, a few studies have described the cognitive status of COVID-19 patients at discharge or after a short follow-up period. In a French study in COVID-19 patients hospitalized in an ICU, 33\% out of 45 patients had a dysexecutive syndrome at discharge [83] (Fig. 1). Another French study reported that after a mean of 110.9 days, the most frequently reported persistent symptoms were fatigue (55\%), dyspnea $(41.7 \%)$, followed by loss of memory (34.2\%), attention deficits $(26.7 \%)$, and sleep disorders $(30.8 \%)$ [100]. A small Chinese study on 29 patients who recovered from COVID-19 infection and 29 controls found lower scores in COVID-19 patients at the continuous performance test (CPT), which measures sustained and selective attention, and the CPT score was positively correlated with their C-reactive protein (CRP) levels [101]. One small Spanish study in 35 COVID-19 patients aged 20-60 years, conducted 10-35 days after hospital discharge, found that patients who reported headache, anosmia, dysgeusia, diarrhea, and those who required oxygen therapy had lower scores in several cognitive domains, such as long-term episodic memory and $\mathrm{WM}$, attention, executive function, processing speed and naming, compared to asymptomatic patients [86]. Performance on digit span backwards was consistently impaired, even if only anosmia and ageusia were present. Preliminary preprint data from a large UK online study on 84,285 people, including 9,201 without and 3,466 with respiratory symptoms, and 361 with laboratory-confirmed SARS-CoV-2 infection, showed that global cognitive scores covaried with respiratory COVID-19 symptom severity after correcting for multiple socio-economical cofounders, including age, and people who required ventilation performed significantly worse [87]. Notably, in this study only a small proportion $(0.76 \%)$ of participants reported having residual symptoms, although this was much higher in patients who required ventilation, in which case $78 \%$ had residual cognitive symptoms. Semantic problem solving, visual attention, and visual WM were the most affected domains, especially in hospitalized patients. The scores in patients who required ventilation were equivalent to 10 -year older subjects in this dataset. One small American study in 57 COVID-19 patients, $88 \%$ of which had documented hypoxemic respiratory failure, showed deficits in working memory, set-shifting, divided attention, and processing speed in $40-55 \%$ of patients, which were not significantly associated with intubation length or the time from extubation to assessment, psychiatric diagnosis, or preexisting cardiovascular/metabolic disease [102]. Preliminary preprint data on Long COVID-19 symptoms after 7 months in a sample of 3,762 subjects support deficits in attention, short-term memory and executive functions, with a great impact on the ability to return to work [103].

Is this dysexecutive/frontal syndrome characteristic of COVID-19 infection? Deficits in executive function are also prominent in patients with acute respiratory distress syndrome (ARDS) [104-106], and a significant percentage of ARDS survivors suffer long-term cognitive impairment with prominent dysexecutive traits [107], as part of PICS [106]. The major risk factors for the development of PICS are age, prior cognitive deficits, delirium, sepsis, sleep deprivation, ARDS, prolonged mechanical ventilation, and multiorgan failure [107-109], many of which are experienced by COVID-19 patients 
(Fig. 1). Mechanical ventilation has been associated with executive dysfunction during and after ICU treatment, and is a risk factor for developing delirium [105]. Nevertheless, not all COVID-19 patients who develop cognitive dysfunction in the aftermath have undergone mechanical ventilation, or have been in ICU, so this might be a causal agent as well as a cofactor. A limitation of the available studies on COVID-19 is that many patients are not usually screened for baseline cognitive status, nor for biomarkers of cognitive impairment.

It is important to keep in mind that post-ICU patients frequently experience a worsening of cognition, due to depression, anxiety, and PTSD [113]. PTSD has also been reported in MERS and SARS patients, even 18-30 months after illness [114, 115], and by COVID-19 patients [116]. Subjective cognitive complaints are also frequently reported by COVID-19 patients, in the acute and chronic phase, and in patients with or without a pre-existing psychiatric diagnosis [103, 117]. Subjective complaints often correlate with executive dysfunction, quality of life and heave a substantial impact on patients' ability to return to work [103, 118]. Multiple centers already advise to monitor cognitive and psychological symptoms of PICS, and encourage the use of cognitive behavioral therapy, counseling sessions, and psychological support [119, 120].

To summarize, the etiology of cognitive impairment is probably multifactorial [117].

Discussing the cognitive long-term implications of vascular brain damage due to COVID-19 is beyond the scope of this review, but vascular ischemic and hemorrhagic events are frequently seen in COVID-19 patients $[121,122]$, and the point prevalence of longterm vascular dementia in these patients will need to be ascertained.

Only few studies so far have examined voxel-wise structural, non-lesional changes in patients recovered from COVID-19 [88, 123]. A small study on 13 COVID-19 patients admitted to ICU showed brain atrophy in regions including primarily, but not limited to, frontal regions [88]. A subset of patients had executive dysfunction and deficits in lexical fluency at testing within 2 weeks of ICU discharge, but brain atrophy was present regardless of the presence of cognitive impairment [88]. Another study enrolled 60 COVID-19 patients 3 months after illness, with negative SARS-CoV-2 PCR at the time of enrolment, and 39 age- and sex-matched controls that had not been exposed to SARS-CoV-2 [123]. Their study results are somehow unexpected, as
COVID-19 patients had statistically significantly higher grey matter volumes bilaterally in the olfactory cortex, hippocampus, insula, left rolandic operculum, left Heschl's gyrus and right cingulate gyrus, reduced mean diffusivity, axial diffusivity, and radial diffusivity, and increased fractional anisotropy, which are opposite findings compared to what usually observed in neurodegenerative diseases, and therefore more data are needed to draw definite conclusions.

Lastly, there is general expectation that COVID19 vaccination would bring current epidemy under control. Recent data has shown that influenza and pneumonia vaccination might be associated with reduced risk of $\mathrm{AD}$ [124]. Bidirectional approach to $\mathrm{AD}$ and COVID-19 should include designing of proper studies to evaluate effect of various antiCOVID vaccination on incidence or course of $\mathrm{AD}$.

\section{MANAGEMENT OF PEOPLE WITH DEMENTIA DURING THE COVID-19 OUTBREAK}

\section{Impact of COVID-19 on patients' and caregivers' well-being}

Most of the literature so far has focused on the impact of COVID-19 on AD patients, described as a "double burden", as the pandemic both increases their vulnerability and disrupts their social network, including their access to the healthcare system [39, 125]. Scheduled outpatient activities such as blood sampling or neuroimaging appointments might be postponed or missed altogether, due to hospital management decisions, but also to the reluctance of vulnerable patients to go to the hospital, and a timely diagnosis and initiation of treatment could be delayed in patients referred for diagnostic evaluation [126] (Fig. 2). The 'Digital Divide', i.e., little knowledge of telecommunication and other digitally-based modes of communication, is frequent among elderly people, especially patients with dementia, and they depend primarily on in-person support, which might be lacking. Family members are often banned from visiting long-term care facilities, and patients with dementia might not understand its reason, and feel abandoned [126]. Group activities in nursing homes may also be prohibited, leading to physical and social isolation. This might increase behavioral and psychological symptoms of dementia (BPSD), such as anxiety, agitation, irritability, sleep disturbances, apathy, and depression, which might in turn also impact the individuals' ability to report symptoms of the infection 
$[127,128]$. Social restrictions induce several lifestyle modifications eventually increasing psychological distress in healthy people and even more in patients with dementia, and the lack of social, physical and cognitive stimulation causes in these patients a partial "deprivation syndrome" effect [129].

During quarantine, worsening of cognitive symptoms, particularly of memory and orientation abilities and increased BPSD in patients with cognitive impairment have often been reported, especially in patients with severe dementia [130]. An Argentinian study found that $48 \%$ patients with $\mathrm{AD}$ reported an increased level of anxiety in the context of lockdown [131], and a French study showed higher depression and anxiety rates during the COVID-19 crisis in AD patients [132]. AD is not the only dementia who might be affected by COVID-19. One Italian multicentric study on 4,913 patients with different dementia types showed an increased burden of neuropsychiatric symptoms in $59.6 \%$ of patients with dementia, either worsening of preexisting symptoms $(51.9 \%)$ or new onset (26\%), which required drug modifications in $27.6 \%$ of the cases [129]. Irritability, apathy, agitation, and anxiety were the most frequently reported worsening symptoms, and sleep disorder and irritability the most reported new symptoms. Anxiety and depression were correlated with a diagnosis of $\mathrm{AD}$, mild disease severity, and female gender. Having a diagnosis of dementia with Lewy bodies (DLB) increased the risk of worsening hallucinations and sleep disorders, while FTD increased the risk of aberrant motor behavior and change of appetite.

Worsening of cognition and BPSD have been reported also in patients with mild cognitive impairment (MCI), who have experienced higher levels of apathy during quarantine, clearly increasing over time [133]. A Spanish study in patients with MCI or mild dementia found that only $61 \%$ declared feeling well, $29 \%$ felt sad, $22 \%$ worried, $11 \%$ afraid, $24 \%$ anxious, and $14 \%$ bored [134]. Those living alone reported greater negative psychological effects and sleeping problems. One Italian study in patients at risk for dementia, i.e., patients with subjective cognitive impairment (SCI) and MCI, found that patients led an increased sedentary lifestyle, switched to a more unhealthy diet and had lower engagement in active recreational activities, which can increase the risk of developing dementia [135]. One Dutch study in patients with SCI, MCI, and dementia due to $\mathrm{AD}$ or DLB showed that $46 \%$ of the patients with objective cognitive decline (MCI, dementia) and 38\% of SCIs reported an increase in BPSD, and concerns regarding a faster cognitive decline were reported by $44 \%$ of patients with objective cognitive decline and $14 \%$ of SCIs [136]. $76 \%$ of the caregivers reported an increase in BPSD, and two third reported discontinuation of care, which correlated with a higher caregiver burden [136].

Caregivers have also been highly affected by the pandemic, and higher burden has been associated with longer confinement periods and with caring for more severe cases [131, 137-141] (Fig. 2). Caregivers might be the only point of contact between the patient and the outside world, and being cut off from their personal network, might feel isolated [129]. Across studies, at least two-thirds reported increased distress [136]. Nevertheless, is important to keep in mind that most of these studies lack adequate controls and longitudinal data, and that COVID-19 has had an impact on mental health even in healthy people [142].

\section{Adaptive strategies and challenges for clinical assessment and non-pharmacological interventions}

The healthcare system should plan adequate strategies to counteract these neuropsychological and behavioral consequences of quarantine, also through the use of communication technologies [143]. Indeed, the COVID-19 pandemic has confronted us with new diagnostic challenges, but also, many suggest, with an opportunity to positively revolutionize our diagnostic system [35, 127, 144].

Performing neuropsychological assessments wearing Level 2 personal protective equipment (PPE) with COVID-19 patients poses several logistical challenges [145]. Paper and pencil tasks cannot be taken into the ward during the assessment [145]. For timed tasks, even where is possible to wear a wristwatch, it cannot be seen underneath the PPE, and speaking through a mask to patients with perceptual or cognitive deficits makes bedside cognitive assessment difficult to perform [145]. Moreover, COVID-19 patients often experience debilitating fatigue, which may adversely affect their cognitive performance, and increased anxiety, which can influence the reliability of their cognitive scores [145].

Even in outpatient settings, is not only the Digital Divide wide among elderly and patients with dementia, but in addition, they might have further difficulties in performing a phone or video consultation, as microphone and speakers may be insufficient for some patients with dysarthric speech, hearing, and ambient and background noises may exacerbate these 
difficulties [146]. Additionally, it can be challenging to ensure input from caregivers over the phone, adding to possible barriers for telecommunication as a substitute for face-to-face outpatient consultations. However, telemedicine is having an essential, positive role during this pandemic, with some studies claiming non-inferiority of telemedicine compared with face to face evaluations in terms of patient and caregiver satisfaction, with benefits in increasing access and reducing cost $[147,148]$. Obvious limitations to some parts of the neurological examination, such as fundoscopy or reflexes, might also not be essential in all follow-ups of patients with cognitive impairment.

The important role of non-pharmacological treatments for patients with dementia and their caregivers has been underscored by the COVID-19 crisis (Fig. 2). Having a support network that prevents risks of exposure to COVID-19 and guarantees food and medical supplies, a daily routine with healthy sleeping habits and leisure activities, staying physically and mentally active with cognitive stimulation exercises, and ensuring social contacts using technology should be encouraged $[149,150]$. Emphasis on communicating the situation in an understandable and calming way, including the necessity of PPE, is imperative [151]. Continuous cognitive, social and physical stimulation has previously been used to reduce cognitive decline and modulate BPSD [152, 153] and remain an appropriate approach during the ongoing epidemic. Physical and mental activities have been modified for remote implementation, such as aerobic exercises, yoga, Pilates, music therapy, and singing [40]. Combined patient-caregiver psychoeducational interventions have also been trialed in the context of COVID-19 to reduce BPSD, such as cognitive behavioral therapy, cognitive stimulation therapy, multisensory stimulation, and mindfulness-based intervention [154]. Depending on the country, other strategies have also been adopted such as robots [155], virtual cognitive stimulation therapy [156], television-based assistive integrated technology [134], and virtual reality [157]. Some countries, as South Korea, have distributed "memory aid-packages" to quarantined elderly patients with dementia, containing a variety of helpful items such as guidelines to prevent COVID-19, face masks, exercise tools such as stretching bands, plant raising kits, and learning materials or tools for cognitive activities [138]. In Ireland, in response to the closure of day care centers, the delivery of a 'Golden Moments' pack has been arranged, providing different activities to support people with dementia at home [40].
Lastly, funding for dementia research has been drastically reduced due to COVID-19 [158]. Therefore, action needs to be taken to avoid a pauperization of dementia researchers, and more importantly, detrimental effects on AD patients [158].

\section{CONCLUSION}

As we still are in the peak of the pandemic, most studies focus on acute cognitive symptoms, while longitudinal data are scarce, and whether COVID-19 is the initial pathogenic trigger for further neurodegeneration is yet to be determined. However, current evidence shows a bidirectional relationship between COVID-19 global pandemic and dementia. Indeed, data on cognitive dysfunction in young patients with COVID-19, who do not fall into high-risk age groups for dementia, seem to support a possible frontal type cognitive dysfunction in COVID-19 patients, at least in the acute state [86, 87]. COVID-19 specific biomarkers of cognitive impairment are lacking, but some common features have increasingly been recognized, as a pro-inflammatory profile in the CSF, MRI fronto-temporal hypoperfusion, EEG frontal slowing, and ${ }^{18}$ F-FDG-PET frontal hypometabolism. On the other hand, patients who have already been diagnosed with dementia had to face multiple challenges due to COVID-19, including reduced access to care, isolation, but also increased rates of hospitalization and mortality. This is true across different types of disease (AD, FTD, DLB, vascular dementia) and also across all disease stages (SCI, MCI, dementia). Worsening of cognitive, behavioral, and psychological symptoms of dementia have had an impact on the patients, but also on their caregivers. Non-pharmacological interventions show a potential benefit in improving patients' symptoms and caregivers' burden.

\section{ACKNOWLEDGMENTS}

This research did not receive funding from any agency in the public, commercial, or non-profit sectors.

All authors are members of the EAN Dementia and Cognitive Disorders Scientific Panel. All members of the Management Group of the panel approved the addition of the phrase "the Management Group of the Dementia Panel of the EAN".

Authors' disclosures available online (https:// www.j-alz.com/manuscript-disclosures/21-0335r1). 


\section{REFERENCES}

[1] Ellul MA, Benjamin L, Singh B, Lant S, Michael BD, Easton A, Kneen R, Defres S, Sejvar J, Solomon T (2020) Neurological associations of COVID-19. Lancet Neurol 19, 767-783.

[2] Varatharaj A, Thomas N, Ellul MA, Davies NWS, Pollak TA, Tenorio EL, Sultan M, Easton A, Breen G, Zandi M, Coles JP, Manji H, Al-Shahi Salman R, Menon DK, Nicholson TR, Benjamin LA, Carson A, Smith C, Turner MR, Solomon T, Kneen R, Pett SL, Galea I, Thomas RH, Michael BD, Allen C, Archibald N, Arkell J, Arthur-Farraj P, Baker M, Ball H, Bradley-Barker V, Brown Z, Bruno S, Carey L, Carswell C, Chakrabarti A, Choulerton J, Daher M, Davies R, Di Marco Barros R, Dima S, Dunley R, Dutta D, Ellis R, Everitt A, Fady J, Fearon P, Fisniku L, Gbinigie I, Gemski A, Gillies E, Gkrania-Klotsas E, Grigg J, Hamdalla H, Hubbett J, Hunter N, Huys AC, Ihmoda I, Ispoglou S, Jha A, Joussi R, Kalladka D, Khalifeh H, Kooij S, Kumar G, Kyaw S, Li L, Littleton E, Macleod M, Macleod MJ, Madigan B, Mahadasa V, Manoharan M, Marigold R, Marks I, Matthews P, Mccormick M, Mcinnes C, Metastasio A, Milburn-McNulty P, Mitchell C, Mitchell D, Morgans C, Morris H, Morrow J, Mubarak Mohamed A, Mulvenna P, Murphy L, Namushi R, Newman E, Phillips W, Pinto A, Price DA, Proschel H, Quinn T, Ramsey D, Roffe C, Ross Russell A, Samarasekera N, Sawcer S, Sayed W, Sekaran L, Serra-Mestres J, Snowdon V, Strike G, Sun J, Tang C, Vrana M, Wade R, Wharton C, Wiblin L, Boubriak I, Herman K, Plant G (2020) Neurological and neuropsychiatric complications of COVID-19 in 153 patients: A UK-wide surveillance study. Lancet Psychiatry 7, 875-882.

[3] Alonso-Lana S, Marquié M, Ruiz A, Boada M (2020) Cognitive and neuropsychiatric manifestations of COVID-19 and effects on elderly individuals with dementia. Front Aging Neurosci 12, 588872.

[4] Pinna P, Grewal P, Hall JP, Tavarez T, Dafer RM, Garg R, Osteraas ND, Pellack DR, Asthana A, Fegan K, Patel V, Conners JJ, John S, Silva I Da (2020) Neurological manifestations and COVID-19: Experiences from a tertiary care center at the Frontline. J Neurol Sci 415, 116969.

[5] Pezzini A, Padovani A (2020) Lifting the mask on neurological manifestations of COVID-19. Nat Rev Neurol 16, 636-644.

[6] Matschke J, Lütgehetmann M, Hagel C, Sperhake JP, Schröder AS, Edler C, Mushumba H, Fitzek A, Allweiss L, Dandri M, Dottermusch M, Heinemann A, Pfefferle S, Schwabenland M, Sumner Magruder D, Bonn S, Prinz M, Gerloff C, Püschel K, Krasemann S, Aepfelbacher M, Glatzel M (2020) Neuropathology of patients with COVID-19 in Germany: A post-mortem case series. Lancet Neurol 19, 919-929.

[7] Rogers JP, Chesney E, Oliver D, Pollak TA, McGuire P, Fusar-Poli P, Zandi MS, Lewis G, David AS (2020) Psychiatric and neuropsychiatric presentations associated with severe coronavirus infections: A systematic review and meta-analysis with comparison to the COVID-19 pandemic. Lancet Psychiatry 7, 611-627.

[8] Herman C, Mayer K, Sarwal A (2020) Scoping review of prevalence of neurologic comorbidities in patients hospitalized for COVID-19. Neurology 95, 77-84.

[9] Zhou J, Liu C, Sun Y, Huang W, Ye K (2020) Cognitive disorders associated with hospitalization of COVID-19:
Results from an observational cohort study. Brain Behav Immun 91, 383-392.

[10] Atkins JL, Masoli JAH, Delgado J, Pilling LC, Kuo C-L, Kuchel GA, Melzer D (2020) Preexisting comorbidities predicting COVID-19 and mortality in the UK Biobank Community Cohort. J Gerontol A Biol Sci Med Sci 75, 2224-2230.

[11] Yu Y, Travaglio M, Popovic R, Leal NS, Martins LM (2021) Alzheimer's and Parkinson's diseases predict different COVID-19 outcomes: A UK biobank study. Geriatrics (Basel) 6, 10.

[12] Kuo CL, Pilling LC, Atkins JL, Masoli JAH, Delgado J, Kuchel GA, Melzer D (2020) ApoE e4e4 genotype and mortality with COVID-19 in UK Biobank. J Gerontol A Biol Sci Med Sci 75, 1801-1803.

[13] Matias-Guiu JA, Pytel V, Matías-Guiu J (2020) Death rate due to COVID-19 in Alzheimer's disease and frontotemporal dementia. J Alzheimers Dis 78, 537-541.

[14] Park MD (2020) Macrophages: A Trojan horse in COVID19? Nat Rev Immunol 20, 351.

[15] Zubair AS, McAlpine LS, Gardin T, Farhadian S, Kuruvilla DE, Spudich S (2020) Neuropathogenesis and neurologic manifestations of the coronaviruses in the age of coronavirus disease 2019: A review. JAMA Neurol 77, 1018-1027.

[16] Fenrich M, Mrdenovic S, Balog M, Tomic S, Zjalic M, Roncevic A, Mandic D, Debeljak Z, Heffer M (2020) SARS-CoV-2 dissemination through peripheral nerves explains multiple organ injury. Front Cell Neurosci 14, 229.

[17] Lukiw WJ, Pogue A, Hill JM (2020) SARS-CoV-2 infectivity and neurological targets in the brain. Cell Mol Neurobiol. doi: 10.1007/s10571-020-00947-7.

[18] Chen R, Wang K, Yu J, Chen Z, Wen C, Xu Z (2021) The spatial and cell-type distribution of SARS-CoV-2 receptor ACE2 in human and mouse brain. Front Neurol 11, 573095.

[19] Jacomy H, Fragoso G, Almazan G, Mushynski WE, Talbot PJ (2006) Human coronavirus OC43 infection induces chronic encephalitis leading to disabilities in BALB/C mice. Virology 349, 335-346.

[20] Paniz-Mondolfi A, Bryce C, Grimes Z, Gordon RE, Reidy J, Lednicky J, Sordillo EM, Fowkes M (2020) Central nervous system involvement by severe acute respiratory syndrome coronavirus-2 (SARS-CoV-2). J Med Virol 92, 699-702.

[21] Moriguchi T, Harii N, Goto J, Harada D, Sugawara H, Takamino J, Ueno M, Sakata H, Kondo K, Myose N, Nakao A, Takeda M, Haro H, Inoue O, SuzukiInoue K, Kubokawa K, Ogihara S, Sasaki T, Kinouchi H, Kojin H, Ito M, Onishi H, Shimizu T, Sasaki Y, Enomoto N, Ishihara H, Furuya S, Yamamoto T, Shimada S (2020) A first case of meningitis/encephalitis associated with SARS-Coronavirus-2. Int J Infect Dis 94, 55-58.

[22] Huang YH, Jiang D, Huang JT (2020) SARS-CoV-2 detected in cerebrospinal fluid by PCR in a case of COVID19 encephalitis. Brain Behav Immun 87, 149.

[23] Pensato U, Muccioli L, Cani I, Janigro D, Zinzani PL, Guarino M, Cortelli P, Bisulli F (2021) Brain dysfunction in COVID-19 and CAR-T therapy: Cytokine storm-associated encephalopathy. Ann Clin Transl Neurol 8, 968-979.

[24] Mehta P, McAuley DF, Brown M, Sanchez E, Tattersall RS, Manson JJ (2020) COVID-19: Consider cytokine 
storm syndromes and immunosuppression. Lancet 395, 1033-1034.

[25] Herold T, Jurinovic V, Arnreich C, Hellmuth JC, BergweltBaildon M, Klein M, Weinberger T (2020) Elevated levels of IL-6 and CRP predict the need for mechanical ventilation in COVID-19. J Allergy Clin Immunol 146, 128-136.

[26] Meneses G, Cárdenas G, Espinosa A, Rassy D, PérezOsorio IN, Bárcena B, Fleury A, Besedovsky H, Fragoso G, Sciutto E (2019) Sepsis: Developing new alternatives to reduce neuroinflammation and attenuate brain injury. Ann N Y Acad Sci 1437, 43-56.

[27] Perrin P, Collongues N, Baloglu S, Bedo D, Bassand X, Lavaux T, Gautier-Vargas G, Keller N, Kremer S, FafiKremer S, Moulin B, Benotmane I, Caillard S (2021) Cytokine release syndrome-associated encephalopathy in patients with COVID-19. Eur J Neurol 28, 248-258.

[28] Aceti A, Margarucci LM, Scaramucci E, Orsini M, Salerno G, Di Sante G, Gianfranceschi G, Di Liddo R, Valeriani F, Ria F, Simmaco M, Parnigotto PP, Vitali M, Romano Spica V, Michetti F (2020) Serum S100B protein as a marker of severity in Covid-19 patients. Sci Rep 10, 18665.

[29] Pilotto A, Masciocchi S, Volonghi I, De Giuli V, Caprioli F, Mariotto S, Ferrari S, Bozzetti S, Imarisio A, Risi B, Premi E, Benussi A, Focà E, Castelli F, Zanusso G, Monaco S, Stefanelli P, Gasparotti R, Zekeridou A, McKeon A, Ashton NJ, Blennov K, Zetterberg H, Padovani A (2021) SARS-CoV-2 encephalitis is a cytokine release syndrome: Evidences from cerebrospinal fluid analyses. Clin Infect Dis. doi: 10.1093/cid/ciaa1933.

[30] Jose RJ, Manuel A (2020) COVID-19 cytokine storm: The interplay between inflammation and coagulation. Lancet Respir Med 8, e46-e47.

[31] Guo YR, Cao QD, Hong ZS, Tan YY, Chen SD, Jin HJ, Tan K Sen, Wang DY, Yan Y (2020) The origin, transmission and clinical therapies on coronavirus disease 2019 (COVID-19) outbreak- An update on the status. Mil Med Res 7, 11.

[32] Chang T, Ding Y, Freund M, Johnson R, Schwarz T, Yabu J, Hazlett C, Chiang J, Wulf A, Geschwind D, Butte M, Pasaniuc B (2020) Prior diagnoses and medications as risk factors for COVID-19 in a Los Angeles Health System. medRxiv Prepr Serv Health Sci, doi: 10.1101/2020.07.03. 20145581.

[33] Suzuki M, Hotta M, Nagase A, Yamamoto Y, Hirakawa N, Satake Y, Nagata Y, Suehiro T, Kanemoto H, Yoshiyama K, Mori E, Hashimoto M, Ikeda M (2020) The behavioral pattern of patients with frontotemporal dementia during the COVID-19 pandemic. Int Psychogeriatr 32, 1231-1234.

[34] Gerritsen DL, Oude Voshaar RC (2020) The effects of the COVID-19 virus on mental healthcare for older people in the Netherlands. Int Psychogeriatr 32, 1353-1356.

[35] Simonetti A, Pais C, Jones M, Cipriani MC, Janiri D, Monti L, Landi F, Bernabei R, Liperoti R, Sani G (2020) Neuropsychiatric symptoms in elderly with dementia during COVID-19 pandemic: Definition, treatment, and future directions. Front Psychiatry 11, 579842.

[36] Batty GD, Deary IJ, Luciano M, Altschul DM, Kivimäki M, Gale CR (2020) Psychosocial factors and hospitalisations for COVID-19: Prospective cohort study based on a community sample. Brain Behav Immun 89, 569-578.

[37] Xie W, Campbell S, Zhang W (2020) Working memory capacity predicts individual differences in social-distancing compliance during the COVID-19 pandemic in the United States. Proc Natl Acad Sci U S A 117, 1766717674.
[38] Covino M, De Matteis G, Santoro M, Sabia L, Simeoni B, Candelli M, Ojetti V, Franceschi F (2020) Clinical characteristics and prognostic factors in COVID-19 patients aged $\geq 80$ years. Geriatr Gerontol Int 20, 704-708.

[39] Azarpazhooh MR, Amiri A, Morovatdar N, Steinwender S, Rezaei Ardani A, Yassi N, Biller J, Stranges S, Tokazebani Belasi M, Neya SK, Khorram B, Sheikh Andalibi MS, Arsang-Jang S, Mokhber N, Di Napoli M (2020) Correlations between COVID-19 and burden of dementia: An ecological study and review of literature. J Neurol Sci 416, 117013.

[40] Suárez-González A, Livingston G, Cahill S, Hennelly N, Dawson WD, Weidner W, Ferri CP, Matias-Guiu JA, Alladi S, Musyimi CW, Comas-Herrera A (2020) Impact and mortality of COVID-19 on people living with dementia: Cross-country report. https://ltccovid.org/wpcontent/uploads/2020/08/International-report-on-theimpact-of-COVID-19-on-people-living-with-dementia19-August-2020.pdf.

[41] Hwang J moon, Kim JH, Park JS, Chang MC, Park D (2020) Neurological diseases as mortality predictive factors for patients with COVID-19: A retrospective cohort study. Neurol Sci 41, 2317-2324.

[42] Hashim MJ, Alsuwaidi AR, Khan G (2020) Population risk factors for COVID-19 mortality in 93 countries. $J$ Epidemiol Glob Health 10, 204-208.

[43] Harrison SL, Fazio-Eynullayeva E, Lane DA, Underhill P, Lip GYH (2020) Comorbidities associated with mortality in 31,461 adults with COVID-19 in the United States: A federated electronic medical record analysis. PLoS Med 17, e1003321.

[44] Bianchetti A, Rozzini R, Guerini F, Boffelli S, Ranieri P, Minelli G, Bianchetti L, Trabucchi M (2020) Clinical presentation of COVID19 in dementia patients. J Nutr Health Aging 24, 560-562.

[45] Cesari M, Proietti M (2020) COVID-19 in Italy: Ageism and decision making in a pandemic. J Am Med Dir Assoc 21, 576-577.

[46] Martín-Jiménez P, Muñoz-García MI, Seoane D, RocaRodríguez L, García-Reyne A, Lalueza A, Maestro G, Folgueira D, Blanco-Palmero VA, Herrero-San Martín A, Llamas-Velasco S, Pérez-Martínez DA, GonzálezSánchez M, Villarejo-Galende A (2020) Cognitive impairment is a common comorbidity in deceased COVID19 patients: A hospital-based retrospective cohort study. $J$ Alzheimers Dis 78, 1367-1372.

[47] Alzheimer Europe (2020) Alzheimer Europe position regarding the allocation of scarce medical resources for intensive care services during the COVID-19 pandemic. https://www.alzheimer-europe.org/Policy/Our-opinionon/Triage-decisions-during-COVID-19-pandemic.

[48] Jiang X, Coffee M, Bari A, Wang J, Jiang X, Huang J, Shi J, Dai J, Cai J, Zhang T, Wu Z, He G, Huang Y (2020) Towards an artificial intelligence framework for datadriven prediction of coronavirus clinical severity. Comput Mater Contin 63, 537-551.

[49] Rahman MA, Islam K, Rahman S, Alamin M (2020) Neurobiochemical cross-talk between COVID-19 and Alzheimer's disease. Mol Neurobiol 58, 1017-1023.

[50] Hascup ER, Hascup KN (2020) Does SARS-CoV-2 infection cause chronic neurological complications? GeroScience 42, 1083-1087.

[51] Abate G, Memo M, Uberti D (2020) Impact of COVID19 on Alzheimer's disease risk: Viewpoint for research action. Healthcare $\mathbf{8}, 286$. 
[52] Li J, Long X, Huang H, Tang J, Zhu C, Hu S, Wu J, Li J, Lin Z, Xiong N (2020) Resilience of Alzheimer's disease to COVID-19. J Alzheimers Dis 77, 67-73.

[53] Kehoe PG, Wong S, Al Mulhim N, Palmer LE, Miners JS (2016) Angiotensin-converting enzyme 2 is reduced in Alzheimer's disease in association with increasing amyloid- $\beta$ and tau pathology. Alzheimers Res Ther 8,50 .

[54] Ding Q, Shults N V, Harris BT, Suzuki YJ (2020) Angiotensin-converting enzyme 2 (ACE2) is upregulated in Alzheimer's disease brain. bioRxiv, doi: 10.1101/2020. 10.08.331157.

[55] Liu CC, Kanekiyo T, Xu H, Bu G (2013) Apolipoprotein e and Alzheimer disease: Risk, mechanisms and therapy. Nat Rev Neurol 9, 106-118.

[56] Kuo C-L, Pilling LC, Atkins JL, Masoli JAH, Delgado J, Kuchel GA, Melzer D (2020) APOE e4 genotype predicts severe COVID-19 in the UK Biobank Community Cohort. J Gerontol A Biol Sci Med Sci 75, 2231-2232.

[57] Nikogosov DA, Shevlyakov AD, Baranova A V (2020) Comment on "ApoE e4e4 genotype and mortality with COVID-19 in UK Biobank" by Kuo et al. J Gerontol A Biol Sci Med Sci 75, 2233-2234.

[58] Kuo C-L, Melzer D (2020) Response to Comment on "ApoE e4e4 genotype and mortality with COVID-19 in UK Biobank" by Kuo et al. J Gerontol A Biol Sci Med Sci 75, 2235-2236.

[59] Motta C, Finardi A, Toniolo S, Di Lorenzo F, Scaricamazza E, Loizzo S, Mercuri NB, Furlan R, Koch G, Martorana A (2020) Protective role of cerebrospinal fluid inflammatory cytokines in patients with amnestic mild cognitive impairment and early Alzheimer's disease carrying apolipoprotein E4 genotype. J Alzheimers Dis 76, 681-689.

[60] Guaraldi G, Meschiari M, Cozzi-Lepri A, Milic J, Tonelli R, Menozzi M, Franceschini E, Cuomo G, Orlando G, Borghi V, Santoro A, Di Gaetano M, Puzzolante C, Carli F, Bedini A, Corradi L, Fantini R, Castaniere I, Tabbì L, Girardis M, Tedeschi S, Giannella M, Bartoletti M, Pascale R, Dolci G, Brugioni L, Pietrangelo A, Cossarizza A, Pea F, Clini E, Salvarani C, Massari M, Viale PL, Mussini C (2020) Tocilizumab in patients with severe COVID-19: A retrospective cohort study. Lancet Rheumatol 2, e474e484.

[61] Huet T, Beaussier H, Voisin O, Jouveshomme S, Dauriat G, Lazareth I, Sacco E, Naccache JM, Bézie Y, Laplanche S, Le Berre A, Le Pavec J, Salmeron S, Emmerich J, Mourad JJ, Chatellier G, Hayem G (2020) Anakinra for severe forms of COVID-19: A cohort study. Lancet Rheumatol 2, e393-e400.

[62] Heneka MT, Carson MJ, Khoury J El, Landreth GE, Brosseron F, Feinstein DL, Jacobs AH, Wyss-Coray T, Vitorica J, Ransohoff RM, Herrup K, Frautschy SA, Finsen B, Brown GC, Verkhratsky A, Yamanaka K, Koistinaho J, Latz E, Halle A, Petzold GC, Town T, Morgan D, Shinohara ML, Perry VH, Holmes C, Bazan NG, Brooks DJ, Hunot S, Joseph B, Deigendesch N, Garaschuk O, Boddeke E, Dinarello CA, Breitner JC, Cole GM, Golenbock DT, Kummer MP (2015) Neuroinflammation in Alzheimer's disease. Lancet Neurol 14, 388-405.

[63] Motta M, Imbesi R, Di Rosa M, Stivala F, Malaguarnera L (2007) Altered plasma cytokine levels in Alzheimer's disease: Correlation with the disease progression. Immunol Lett 114, 46-51.
[64] Cojocaru IM, Cojocaru M, Miu G, Sapira V (2011) Study of interleukin-6 production in Alzheimer's disease. Rom J Intern Med 49, 55-8.

[65] Brosseron F, Krauthausen M, Kummer M, Heneka MT (2014) Body fluid cytokine levels in mild cognitive impairment and Alzheimer's disease: A comparative overview. Mol Neurobiol 50, 534-44.

[66] Bialuk I, Taranta A, Winnicka MM (2018) IL-6 deficiency alters spatial memory in 4- and 24-month-old mice. $\mathrm{Neu}$ robiol Learn Mem 155, 21-29.

[67] Rachal Pugh C, Fleshner M, Watkins LR, Maier SF, Rudy JW (2001) The immune system and memory consolidation: A role for the cytokine IL-1ß. Neurosci Biobehav Rev 25, 29-41.

[68] Sheng JG, Ito K, Skinner RD, Mrak RE, Rovnaghi CR, Van Eldik LJ, Griffin WST (1996) In vivo and in vitro evidence supporting a role for the inflammatory cytokine interleukin-1 as a driving force in Alzheimer pathogenesis. Neurobiol Aging 17, 761-6.

[69] Jaturapatporn D, Isaac MGEKN, McCleery J, Tabet N (2012) Aspirin, steroidal and non-steroidal anti-inflammatory drugs for the treatment of Alzheimer's disease. Cochrane Database Syst Rev, CD006378.

[70] Tejera D, Mercan D, Sanchez-Caro JM, Hanan M, Greenberg D, Soreq H, Latz E, Golenbock D, Heneka MT (2019) Systemic inflammation impairs microglial $\mathrm{A} \beta$ clearance through NLRP 3 inflammasome. EMBO J 38, e101064.

[71] Heneka MT, Golenbock D, Latz E, Morgan D, Brown R (2020) Immediate and long-term consequences of COVID-19 infections for the development of neurological disease. Alzheimers Res Ther 12, 69.

[72] Garcia-Revilla J, Deierborg T, Venero JL, Boza-Serrano A (2020) Hyperinflammation and fibrosis in severe COVID19 patients: Galectin-3, a target molecule to consider. Front Immunol 11, 2069.

[73] Tao CC, Cheng KM, Ma YL, Hsu WL, Chen YC, Fuh JL, Lee WJ, Chao CC, Lee EHY (2020) Galectin-3 promotes $\mathrm{A} \beta$ oligomerization and $\mathrm{A} \beta$ toxicity in a mouse model of Alzheimer's disease. Cell Death Differ 27, 192-209.

[74] Poloni TE, Carlos AF, Cairati M, Cutaia C, Medici V, Marelli E, Ferrari D, Galli A, Bognetti P, Davin A, Cirrincione A, Ceretti A, Cereda C, Ceroni M, Tronconi L, Vitali S, Guaita A (2020) Prevalence and prognostic value of delirium as the initial presentation of COVID-19 in the elderly with dementia: An Italian retrospective study. EClinicalMedicine 26, 100490.

[75] Isaia G, Marinello R, Tibaldi V, Tamone C, Bo M (2020) Atypical presentation of Covid-19 in an older adult with severe Alzheimer disease. Am J Geriatr Psychiatry 28, 790-791.

[76] Graham NSN, Junghans C, Downes R, Sendall C, Lai H, McKirdy A, Elliott P, Howard R, Wingfield D, Priestman M, Ciechonska M, Cameron L, Storch M, Crone MA, Freemont PS, Randell P, McLaren R, Lang N, Ladhani S, Sanderson F, Sharp DJ (2020) SARS-CoV-2 infection, clinical features and outcome of COVID-19 in United Kingdom nursing homes. J Infect 81, 411-419.

[77] Annweiler C, Sacco G, Salles N, Aquino J-P, Gautier J, Berrut G, Guérin O, Gavazzi G (2020) National French survey of COVID-19 symptoms in people aged 70 and over. Clin Infect Dis 72, 490-494.

[78] Helms J, Kremer S, Merdji H, Schenck M, Severac F, Clere-Jehl R, Studer A, Radosavljevic M, Kummerlen C, Monnier A, Boulay C, Fafi-Kremer S, Castelain V, Ohana M, Anheim M, Schneider F, Meziani F (2020) Delirium 
and encephalopathy in severe COVID-19: A cohort analysis of ICU patients. Crit Care 24, 491.

[79] Cani I, Barone V, D’Angelo R, Pisani L, Allegri V, Spinardi L, Malpassi P, Fasano L, Rinaldi R, Fanti S, Cortelli P, Guarino M (2020) Frontal encephalopathy related to hyperinflammation in COVID-19. J Neurol 268, 16-19.

[80] Delorme C, Paccoud O, Kas A, Hesters A, Bombois S, Shambrook P, Boullet A, Doukhi D, Le Guennec L, Godefroy N, Maatoug R, Fossati P, Millet B, Navarro V, Bruneteau G, Demeret S, Pourcher V (2020) Covid19-related encephalopathy: A case series with brain FDG-PET/CT findings. Eur J Neurol 27, 2651-2657.

[81] Kas A, Soret M, Pyatigoskaya N, Habert MO, Hesters A, Le Guennec L, Paccoud O, Bombois S, Delorme C (2021) The cerebral network of COVID-19-related encephalopathy: A longitudinal voxel-based 18F-FDG-PET study. Eur J Nucl Med Mol Imaging, doi: 10.1007/s00259-02005178-y.

[82] Toniolo S, Di Lorenzo F, Scarioni M, Frederiksen KS, Nobili F (2021) Is the frontal lobe the primary target of SARS-CoV-2? J Alzheimers Dis 81, 75-81.

[83] Helms J, Kremer S, Merdji H, Clere-Jehl R, Schenck M, Kummerlen C, Collange O, Boulay C, Fafi-Kremer S, Ohana M, Anheim M, Meziani F (2020) Neurologic features in severe SARS-COV-2 infection. NEngl J Med 382, 2268-2270.

[84] Muccioli L, Pensato U, Cani I, Guarino M, Cortelli P, Bisulli F (2020) COVID-19-associated encephalopathy and cytokine-mediated neuroinflammation. Ann Neurol 88, 860-861.

[85] Pilotto A, Odolini S, Masciocchi S, Comelli A, Volonghi I, Gazzina S, Nocivelli S, Pezzini A, Focà E, Caruso A, Leonardi M, Pasolini MP, Gasparotti R, Castelli F, Ashton NJ, Blennow K, Zetterberg H, Padovani A (2020) Steroidresponsive encephalitis in coronavirus disease 2019. Ann Neurol 88, 423-427.

[86] Almeria M, Cejudo JC, Sotoca J, Deus J, Krupinski J (2020) Cognitive profile following COVID-19 infection: Clinical predictors leading to neuropsychological impairment. Brain, Behav Immun Health 9, 100163.

[87] Hampshire A, Trender W, Chamberlain SR, Jolly A, Grant JE, Patrick F, Mazibuko N, Williams S, Barnby JM, Hellyer P, Mehta MA (2020) Cognitive deficits in people who have recovered from COVID-19 relative to controls: An $N=84,285$ online study. medRxiv, doi.org/10.1101/ 2020.10.20.20215863.

[88] Beaud V, Crottaz-Herbette S, Dunet V, Vaucher J, BernardValnet R, Du Pasquier R, Bart PA, Clarke S (2021) Pattern of cognitive deficits in severe COVID-19. J Neurol Neurosurg Psychiatry 92, 567-568.

[89] Antony AR, Haneef Z (2020) Systematic review of EEG findings in 617 patients diagnosed with COVID-19. Seizure 83, 234-241.

[90] Karimi-Galougahi M, Yousefi-Koma A, Bakhshayeshkaram M, Raad N, Haseli S (2020) 18FDG PET/CT scan reveals hypoactive orbitofrontal cortex in anosmia of COVID-19. Acad Radiol 27, 1042-1043.

[91] Fong TG, Bogardus ST, Daftary A, Auerbach E, Blumenfeld H, Modur S, Leo-Summers L, Seibyl J, Inouye SK (2006) Cerebral perfusion changes in older delirious patients using 99mTc HMPAO SPECT. J Gerontol A Biol Sci Med Sci 61, 1294-1299.

[92] Haggstrom LR, Nelson JA, Wegner EA, Caplan GA (2017) 2-18F-fluoro-2-deoxyglucose positron emission tomography in delirium. J Cereb Blood Flow Metab 37, 3556-3567.
[93] Beach SR, Praschan NC, Hogan C, Dotson S, Merideth F, Kontos N, Fricchione GL, Smith FA (2020) Delirium in COVID-19: A case series and exploration of potential mechanisms for central nervous system involvement. Gen Hosp Psychiatry 65, 47-53.

[94] Blazhenets G, Schröter N, Bormann T, Thurow J, Wagner D, Frings L, Weiller C, Meyer PT, Dressing A, Hosp JA (2021) Slow but evident recovery from neocortical dysfunction and cognitive impairment in a series of chronic COVID-19 patients. J Nucl Med, doi: 10.2967/ jnumed.121.262128.

[95] Hosp JA, Dressing A, Blazhenets G, Bormann T, Rau A, Schwabenland M, Thurow J, Wagner D, Waller C, Niesen WD, Frings L, Urbach H, Prinz M, Weiller C, Schroeter N, Meyer PT (2021) Cognitive impairment and altered cerebral glucose metabolism in the subacute stage of COVID-19. Brain 144, 1263-1276.

[96] Subudhi AW, Miramon BR, Granger ME, Roach RC (2009) Frontal and motor cortex oxygenation during maximal exercise in normoxia and hypoxia. J Appl Physiol 106, 1153-1158.

[97] Ye M, Ren Y, Lv T (2020) Encephalitis as a clinical manifestation of COVID-19. Brain Behav Immun 88, 945-946.

[98] Romoli M, Jelcic I, Bernard-Valnet R, García Azorín D, Mancinelli L, Akhvlediani T, Monaco S, Taba P, Sellner J (2020) A systematic review of neurological manifestations of SARS-CoV-2 infection: The devil is hidden in the details. Eur J Neurol 27, 1712-1726.

[99] Katsanos AH, Palaiodimou L, Zand R, Yaghi S, Kamel H, Navi BB, Turc G, Romoli M, Sharma VK, Mavridis D, Shahjouei S, Catanese L, Shoamanesh A, Vadikolias K, Tsioufis K, Lagiou P, Alexandrov A V, Tsiodras S, Tsivgoulis G (2020) The impact of SARS-CoV-2 on stroke epidemiology and care: A meta-analysis. Ann Neurol 89, 380-388.

[100] Garrigues E, Janvier P, Kherabi Y, Le Bot A, Hamon A, Gouze H, Doucet L, Berkani S, Oliosi E, Mallart E, Corre F, Zarrouk V, Moyer JD, Galy A, Honsel V, Fantin B, Nguyen Y (2020) Post-discharge persistent symptoms and health-related quality of life after hospitalization for COVID-19. J Infect 81, e4-e6.

[101] Zhou H, Lu S, Chen J, Wei N, Wang D, Lyu H, Shi C, Hu $S$ (2020) The landscape of cognitive function in recovered COVID-19 patients. J Psychiatr Res 129, 98-102.

[102] Jaywant A, Michael Vanderlind W, Alexopoulos GS, Fridman CB, Perlis RH, Gunning FM (2020) Frequency and profile of objective cognitive deficits in hospitalized patients recovering from COVID-19. Neuropsychopharmacology, doi: 10.1038/s41386-021-00978-8.

[103] Davis HE, Assaf GS, McCorkell L, Wei H, Low RJ, Re'em Y, Redfield S, Austin JP, Akrami A (2020) Characterizing long COVID in an international cohort: 7 months of symptoms and their impact. medRxiv, doi.org/10.1101/ 2020.12.24.20248802.

[104] Ardila A, Lahiri D (2020) Executive dysfunction in COVID-19 patients. Diabetes Metab Syndr Clin Res Rev 14, 1377-1378.

[105] Stollings JL, Wilson JE, Jackson JC, Ely EW (2016) Executive dysfunction following critical illness: Exploring risk factors and management options in geriatric populations. Curr Behav Neurosci Rep 3, 176-184.

[106] Rawal G, Yadav S, Kumar R (2017) Post-intensive care syndrome: An overview. J Transl Intern Med 5, 90-92.

[107] Sasannejad C, Ely EW, Lahiri S (2019) Long-term cognitive impairment after acute respiratory distress syndrome: 
A review of clinical impact and pathophysiological mechanisms. Crit Care 23, 352.

[108] Desai S V., Law TJ, Needham DM (2011) Long-term complications of critical care. Crit Care Med 39, 371-379.

[109] Morandi A, Zambon A, Di Santo SG, Mazzone A, Cherubini A, Mossello E, Bo M, Marengoni A, Bellelli G, Castagna A (2020) Understanding factors associated with psychomotor subtypes of delirium in older inpatients with dementia. J Am Med Dir Assoc 21, 486-492.e6.

[110] Pun BT, Badenes R, Heras La Calle G, Orun OM, Chen W, Raman R, Simpson B-GK, Wilson-Linville S, Olmedillo BH, Vallejo De La Cueva A, Van Der Jagt M, Casado RN, Leal Sanz P, Orhun G, Ferrer Gómez C, Núñez Vázquez K, Otero PP, Taccone FS, Curto EG, Caricato A, Woien H, Lacave G, O'Neal HR, Peterson SJ, Brummel NE, Girard TD, Ely W, Pandharipande P (2021) Prevalence and risk factors for delirium in critically ill patients with COVID19 (COVID-D): A multicentre cohort study. Lancet Respir 9, 239-250.

[111] Ostuzzi G, Gastaldon C, Papola D, Fagiolini A, Dursun S, Taylor D, Correll CU, Barbui C (2020) Pharmacological treatment of hyperactive delirium in people with COVID-19: Rethinking conventional approaches. Ther Adv Psychopharmacol 10, 2045125320942703.

[112] Ostuzzi G, Papola D, Gastaldon C, Schoretsanitis G, Bertolini F, Amaddeo F, Cuomo A, Emsley R, Fagiolini A, Imperadore G, Kishimoto T, Michencigh G, Nosé M, Purgato M, Serdar D, Stubbs B, Taylor D, Thornicroft G, Ward PB, Hiemke C, Correll CU, Barbui C (2020) Safety of psychotropic medications in people with COVID-19: Evidence review and practical recommendations. BMC Med 18, 215.

[113] Mikkelsen ME, Christie JD, Lanken PN, Biester RC, Thompson BT, Bellamy SL, Localio AR, EjigayehuDemissie, Hopkins RO, Angus DC (2012) The adult respiratory distress syndrome cognitive outcomes study: Long-term neuropsychological function in survivors of acute lung injury. Am J Respir Crit Care Med 185, 13071315.

[114] Lee SH, Shin HS, Park HY, Kim JL, Lee JJ, Lee H, Won SD, Han W (2019) Depression as a mediator of chronic fatigue and post-traumatic stress symptoms in middle east respiratory syndrome survivors. Psychiatry Investig 16, $59-64$.

[115] Mak IWC, Chu CM, Pan PC, Yiu MGC, Ho SC, Chan VL (2010) Risk factors for chronic post-traumatic stress disorder (PTSD) in SARS survivors. Gen Hosp Psychiatry 32, 590-598.

[116] Janiri D, Carfî A, Kotzalidis GD, Bernabei R, Landi F, Sani G (2021) Posttraumatic stress disorder in patients after severe COVID-19 infection. JAMA Psychiatry 78, 567-569.

[117] Kaseda ET, Levine AJ (2020) Post-traumatic stress disorder: A differential diagnostic consideration for COVID-19 survivors. Clin Neuropsychol 34, 1498-1514.

[118] Miskowiak KW, Johnsen S, Sattler SM, Nielsen S, Kunalan K, Rungby J, Lapperre T, Porsberg CM (2021) Cognitive impairments four months after COVID-19 hospital discharge: Pattern, severity and association with illness variables. Eur Neuropsychopharmacol 46, 39-48.

[119] Barker-Davies RM, O'Sullivan O, Senaratne KPP, Baker P, Cranley M, Dharm-Datta S, Ellis H, Goodall D, Gough M, Lewis S, Norman J, Papadopoulou T, Roscoe D, Sherwood D, Turner P, Walker T, Mistlin A, Phillip R, Nicol AM, Bennett AN, Bahadur S (2020) The Stanford Hall consensus statement for post-COVID-19 rehabilitation. $\mathrm{Br}$ J Sports Med 54, 949-959.

[120] Iannaccone S, Castellazzi P, Tettamanti A, Houdayer E, Brugliera L, de Blasio F, Cimino P, Ripa M, Meloni C, Alemanno F, Scarpellini P (2020) Role of rehabilitation department for adult individuals with COVID-19: The experience of the San Raffaele Hospital of Milan. Arch Phys Med Rehabil 101, 1656-1661.

[121] Mahammedi A, Saba L, Vagal A, Leali M, Rossi A, Gaskill M, Sengupta S, Zhang B, Carriero A, Bachir S, Crivelli $\mathrm{P}$, Paschè A, Premi E, Padovani A, Gasparotti $R$ (2020) Imaging in neurological disease of hospitalized COVID-19 patients: An Italian multicenter retrospective observational study. Radiology 297, E270-E273.

[122] Abou-Ismail MY, Diamond A, Kapoor S, Arafah Y, Nayak L (2020) The hypercoagulable state in COVID-19: Incidence, pathophysiology, and management. Thromb Res 194, 101-115.

[123] Lu Y, Li X, Geng D, Mei N, Wu PY, Huang CC, Jia T, Zhao Y, Wang D, Xiao A, Yin B (2020) Cerebral microstructural changes in COVID-19 patients - An MRI-based 3-month follow-up study. EClinicalMedicine 25, 100484.

[124] Could Common Vaccines Protect Against Alzheimer, Last updated 2020, Accessed on 2020, https://www. alzforum.org/news/conference-coverage/could-commonvaccines-protect-against-alzheimers-disease.

[125] Tousi B (2020) Dementia care in the time of COVID-19 pandemic. J Alzheimers Dis 76, 475-479.

[126] Mok VCT, Pendlebury S, Wong A, Alladi S, Au L, Bath PM, Biessels GJ, Chen C, Cordonnier C, Dichgans M, Dominguez J, Gorelick PB, Kim SY, Kwok T, Greenberg SM, Jia J, Kalaria R, Kivipelto M, Naegandran K, Lam LCW, Lam BYK, Lee ATC, Markus HS, O'Brien J, Pai MC, Pantoni L, Sachdev P, Skoog I, Smith EE, Srikanth V, Suh GH, Wardlaw J, Ko H, Black SE, Scheltens P (2020) Tackling challenges in care of Alzheimer's disease and other dementias amid the COVID-19 pandemic, now and in the future. Alzheimers Dement 16, 15711581.

[127] Holmes EA, O'Connor RC, Perry VH, Tracey I, Wessely S, Arseneault L, Ballard C, Christensen H, Cohen Silver R, Everall I, Ford T, John A, Kabir T, King K, Madan I, Michie S, Przybylski AK, Shafran R, Sweeney A, Worthman CM, Yardley L, Cowan K, Cope C, Hotopf M, Bullmore E (2020) Multidisciplinary research priorities for the COVID-19 pandemic: A call for action for mental health science. Lancet Psychiatry 7, 547-560.

[128] Keng A, Brown EE, Rostas A, Rajji TK, Pollock BG, Mulsant BH, Kumar S (2020) Effectively caring for individuals with behavioral and psychological symptoms of dementia during the COVID-19 pandemic. Front Psychiatry 11, 573367.

[129] Cagnin A, Di Lorenzo R, Marra C, Bonanni L, Cupidi C, Laganà V, Rubino E, Vacca A, Provero P, Isella V, Vanacore N, Agosta F, Appollonio I, Caffarra P, Pettenuzzo I, Sambati R, Quaranta D, Guglielmi V, Logroscino G, Filippi M, Tedeschi G, Ferrarese C, Rainero I, Bruni AC (2020) Behavioral and psychological effects of coronavirus disease-19 quarantine in patients with dementia. Front Psychiatry 11, 578015.

[130] Canevelli M, Valletta M, Toccaceli Blasi M, Remoli G, Sarti G, Nuti F, Sciancalepore F, Ruberti E, Cesari M, Bruno G (2020) Facing dementia during the COVID-19 outbreak. J Am Geriatr Soc 68, 1673-1676. 
[131] Cohen G, Russo MJ, Campos JA, Allegri RF (2020) Living with dementia: Increased level of caregiver stress in times of COVID-19. Int Psychogeriatr 32, 1377-1381.

[132] El Haj M, Altintas E, Chapelet G, Kapogiannis D, Gallouj K (2020) High depression and anxiety in people with Alzheimer's disease living in retirement homes during the covid-19 crisis. Psychiatry Res 291, 113294.

[133] Lara B, Carnes A, Dakterzada F, Benitez I, Piñol-Ripoll G (2020) Neuropsychiatric symptoms and quality of life in Spanish patients with Alzheimer's disease during the COVID-19 lockdown. Eur J Neurol 27, 1744-1747.

[134] Goodman-Casanova JM, Dura-Perez E, Guzman-Parra J, Cuesta-Vargas A, Mayoral-Cleries F (2020) Telehealth home support during COVID-19 confinement for community-dwelling older adults with mild cognitive impairment or mild dementia: Survey study. J Med Internet Res 22, e19434.

[135] Di Santo SG, Franchini F, Filiputti B, Martone A, Sannino S (2020) The effects of COVID-19 and quarantine measures on the lifestyles and mental health of people over 60 at increased risk of dementia. Front Psychiatry 11, 578628.

[136] van Maurik IS, Bakker ED, van den Buuse S, Gillissen F, van de Beek M, Lemstra E, Mank A, van den Bosch KA, van Leeuwenstijn M, Bouwman FH, Scheltens P, van der Flier WM (2020) Psychosocial effects of corona measures on patients with dementia, mild cognitive impairment and subjective cognitive decline. Front Psychiatry 11, 585686.

[137] Brodaty H, Donkin M (2009) Family caregivers of people with dementia. Dialogues Clin Neurosci 11, 217-28.

[138] Ryoo N, Pyun J-M, Baek MJ, Suh J, Kang MJ, Wang MJ, Youn YC, Yang DW, Kim SY, Park YH, Kim S (2020) Coping with dementia in the middle of the COVID-19 pandemic. J Korean Med Sci 35, e383.

[139] Savla J, Roberto KA, Blieszner R, McCann BR, Hoyt E, Knight AL (2020) Dementia caregiving during the "stayat-home" phase of COVID-19 pandemic. J Gerontol B Psychol Sci Soc Sci 76, e241-e245.

[140] Greenberg NE, Wallick A, Brown LM (2020) Impact of COVID-19 pandemic restrictions on community-dwelling caregivers and persons with dementia. Psychol Trauma 12, S220-S221.

[141] Boutoleau-Bretonnière C, Pouclet-Courtemanche $H$, Gillet A, Bernard A, Deruet AL, Gouraud I, Mazoue A, Lamy E, Rocher L, Kapogiannis D, El Haj M (2020) The effects of confinement on neuropsychiatric symptoms in Alzheimer's disease during the COVID-19 crisis. J Alzheimers Dis 76, 41-47.

[142] Xin M, Luo S, She R, Yu Y, Wang S, Tao F, Zhao J, Hu D, Gu J, Wang H, Wang Z, Hu G, Li L, Ma L, Zhang J, Li L, Zhang G, Lin D, Cai Y, You H, Lau JTF (2020) Negative cognitive and psychological correlates of mandatory quarantine during the initial COVID-19 outbreak in China. Am Psychol 75, 607-617.

[143] Cuffaro L, Di Lorenzo F, Bonavita S, Tedeschi G, Leocani L, Lavorgna L (2020) Dementia care and COVID-19 pandemic: A necessary digital revolution. Neurol Sci 41, 1977-1979.

[144] Greenhalgh T, Wherton J, Shaw S, Morrison C (2020) Video consultations for covid-19. BMJ 368, m998.

[145] Coetzer R (2020) First impressions of performing bedside cognitive assessment of COVID-19 inpatients. $J$ Am Geriatr Soc 68, 1389-1390.
[146] Parker CB, Forbes MP, Vahia IV, Forester BP, Jeste DV, Reynolds CF (2020) Facing the change together: Reflections of coping and resilience from American geriatric psychiatrists during COVID-19, Am J Geriatr Psychiatry 28, 1015-1019.

[147] Hatcher-Martin JM, Adams JL, Anderson ER, Bove R, Burrus TM, Chehrenama M, Dolan O'Brien M, Eliashiv DS, Erten-Lyons D, Giesser BS, Moo LR, Narayanaswami P, Rossi MA, Soni M, Tariq N, Tsao JW, Vargas BB, Vota SA, Wessels SR, Planalp H, Govindarajan R (2020) Telemedicine in neurology: Telemedicine Work Group of the American Academy of Neurology update. Neurology 94, 30-38.

[148] Hantke NC, Gould C (2020) Examining older adult cognitive status in the time of COVID-19. J Am Geriatr Soc 68, 1387-1389

[149] Canevelli M, Bruno G, Cesari M (2020) Providing simultaneous COVID-19-sensitive and dementia-sensitive care as we transition from crisis care to ongoing care. $J \mathrm{Am}$ Med Dir Assoc 21, 968-969.

[150] Banskota S, Healy M, Goldberg EM (2020) 15 smartphone apps for older adults to use while in isolation during the Covid-19 pandemic. West J Emerg Med 21, 514-525.

[151] Alzheimer Europe (2020) Alzheimer Europe recommendations on promoting the wellbeing of people with dementia and carers during the COVID-19 pandemic. Wellbeing people with Dement Dur COVID-19 pandemic. https://www.alzheimer-europe.org/Policy/Our-opinionon/Wellbeing-of-people-with-dementia-during-COVID19-pandemic.

[152] Jia RX, Liang JH, Xu Y, Wang YQ (2019) Effects of physical activity and exercise on the cognitive function of patients with Alzheimer disease: A meta-analysis. BMC Geriatr 19, 181.

[153] Aguirre E, Woods RT, Spector A, Orrell M (2013) Cognitive stimulation for dementia: A systematic review of the evidence of effectiveness from randomised controlled trials. Ageing Res Rev 12, 253-62.

[154] Alves GS, Casali ME, Veras AB, Carrilho CG, Bruno Costa E, Rodrigues VM, Dourado MCN (2020) A systematic review of home-setting psychoeducation interventions for behavioral changes in dementia: Some lessons for the COVID-19 pandemic and post-pandemic assistance. Front Psychiatry 11, 577871.

[155] Lee OEK, Davis B (2020) Adapting 'Sunshine,' a socially assistive chat robot for older adults with cognitive impairment: A pilot study. J Gerontol Soc Work 63, 696-698.

[156] Cheung G, Peri K (2020) Challenges to dementia care during COVID-19: Innovations in remote delivery of group Cognitive Stimulation Therapy. Aging Ment Health 25, 977-979.

[157] Gao Z, Lee JE, McDonough DJ, Albers C (2020) Virtual reality exercise as a coping strategy for health and wellness promotion in older adults during the COVID-19 pandemic. J Clin Med 9, 1986.

[158] Alzheimer Europe (2020) Alzheimer Europe position on supporting dementia research in unprecedented circumstances. https://www.alzheimereurope.org/Publications/ Alzheimer-Europe-Reports. 